\title{
EFFECT OF THE AQUEOUS EXTRACT OF EUPHORBIA GUYONIANA (EUPHORBIACEAE) ON PATHOGENIC BACTERIA FROM LAND-BASED SOURCES
}

\author{
BOUMAZA, S.* - BouchenAK, O. - YAHIAOUI, K. - TOUBAL, S. - El HADDAD, D. - ARAB, K. \\ Laboratory of Valorization and Conservation of Biological Resources (VALCOR), Department \\ of Biology, Faculty of Sciences, University of M'hamed Bougara, 3500 Boumerdes, Algeria \\ (phone: +213-24-912-951; fax: ++213-24-912-951) \\ *Corresponding author \\ e-mail: sarah.boumazal@hotmail.fr; phone: +213-66-531-4176; fax: +213-24-951-738 \\ (Received 27 $7^{\text {th }}$ Mar 2018; accepted $12^{\text {th }}$ Jun 2018)
}

\begin{abstract}
Euphorbia guyoniana is a medicinal plant endemic to Algeria. It is used by local populations for its medicinal properties. This study was to determine the antibacterial effect of the aqueous extract from Euphorbia guyoniana on pathogenic bacteria of telluric origin. The aqueous extract was obtained by confrontation with organic solvents method with a yield of $1.7 \%$. The total content of the flavonoid extract was evaluated by the method of Aluminum Trichloride and was found to be $0.31 \mathrm{mg} E Q / \mathrm{gE}$. The extract obtained was characterized by Infrared Spectroscopy and revealed a richness of phenol, aldehyde and ester then analyzed by High-Performance Liquid Chromatography, which allowed us to identify 27 flavonoid compounds. The extract was tested by the diffusion method on agar, on 12 bacterial strains isolated from a henhouse and identified by VITEK. These strains seem to be sensitive to the flavonoids of Euphorbia guyoniana with MICs varying from 1.47 to $61.78 \mathrm{mg} / \mathrm{ml}$. The order of sensitivity of the bacterial strains to the extract is represented in the following order: Staphylococcus aureus > Streptococcus faecalis > Escherichia coli. Thus, the flavonoids of Euphorbia guyoniana may be an alternative to chemical control of certain pathogenic microorganisms.
\end{abstract}

Keywords: Euphorbia guyoniana, flavonoids, antibacterial activity, HPLC, VITEK

\section{Introduction}

Within microbial communities in the soil, there may be some microorganisms that are pathogens for plants, animals and humans (Raaijmakers, 2009). Soil is a natural habitat that can contain some primary and opportunistic pathogenic bacteria. The rhizosphere may contain certain opportunistic bacteria such as Burkholderia spp., Ochrobactrum spp. and Stenotrophomonas spp. (Berg et al., 2005). Pseudomonas aeruginosa is a highly encountered bacterium in the soil (Colinon et al., 2013). Some primary pathogenic bacteria are natural soil inhabitants, such as Bacillus cereus and Bacillus anthracis, which can cause serious diseases in humans (food poisoning and pneumonia) (Ticknor et al., 2001; Reis et al., 2014). Other bacteria are highly pathogenic to humans such as Clostridium botulinum and Clostridium tetani (Smith, 1978, 1979). There are certain categories of bacteria with a saprophyte life in soil such as Listeria monocytogenes (Freitag et al., 2009). The importance of these pathogens from land-based sources is growing with the increasing practice of monoculture, mainly in the Mediterranean regions (Tramier, 1986).

Control of pathogens from land-based sources has always been difficult, however the use of biocidal soil disinfection products such as chloropicrin and methyl bromide has been found to be very dangerous for humans and useful organisms' cultures. Fortunately, these products have been definitely banned, which does not solve the problem of the control of diseases of land-based origin. Vector control during epidemics 
is achieved through chemical insecticides, but their use continues to give rise to a high level of contamination and ecological imbalance due to the appearance of resistance. This is why the World Health Organization (WHO) insists on the search for new methods of control that are basically biological.

Euphorbiaceae contains several families of chemical compounds such as alkaloids (De Nazare et al., 2005), flavonoids, Cyanogenetic compounds (Hunsa et al., 1995), ellagic acid (Mavar et al., 2004) Saponins (Tripathi and Tiwari, 1980) and terpenes (Mazoir et al., 2008). Among the species endemic to Algeria, Euphorbia guyoniana had a particular importance in the pharmacopoeia. According to Bellakhdar (1997), it is used by many Saharan populations against poisonous bites and stings and various infections. The latex of the plant is used to attack warts and to extirpate thorns.

This study attempts to establish for the first time the effect of the aqueous extract of a medicinal plant (Euphorbia guyoniana) on the human bacterial pathogen in the telluric environment for the purpose of biological control.

\section{Materials and methods}

\section{Plant material}

Experiments were carried out on the aerial and underground parts of Euphorbia guyoniana, collected from the Ghardaïa region (South Algeria) in February 2016. The botanical identification of the species was carried out at the botanical laboratory of the Higher National School of Agronomy (ENSA) in El-Harrach (Algeria). The whole plant (stems, flowers, leaves and roots) was used for the preparation of the extract. The plant material was ground after drying at ambient temperature in dark place in order to preserve the integrity of the molecules. The obtained ground product was stored in a hermetically sealed flask (Photo 1 ).

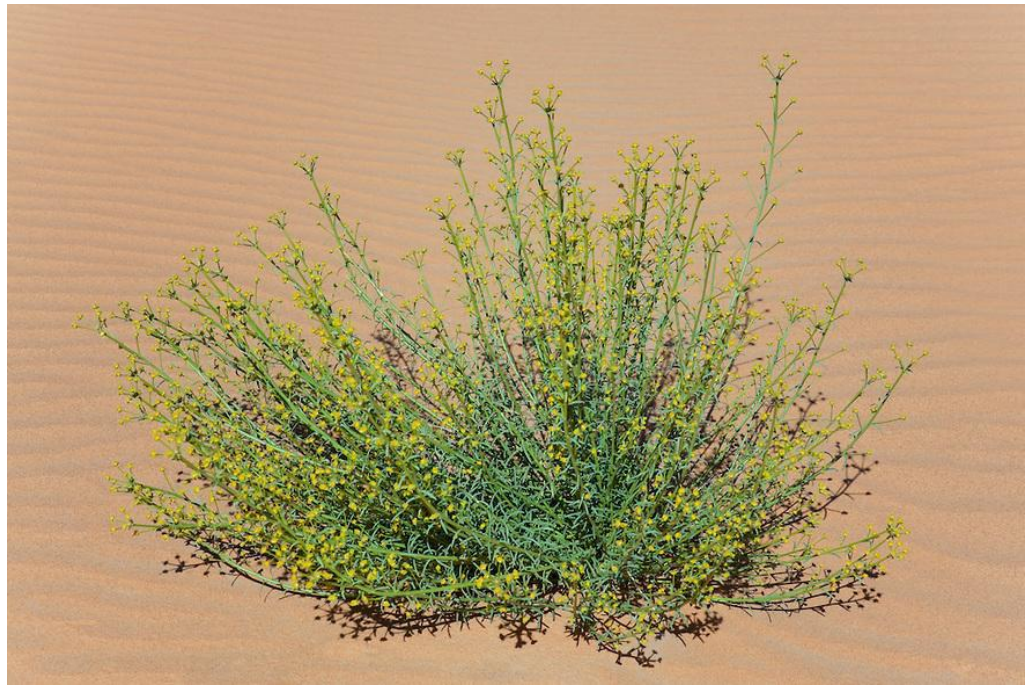

Photo 1. Aerial part of Euphorbia guyoniana

\section{Extraction procedure}

The extraction of flavonoids was carried out according to the Bruneton protocol (1999). The principle of this technique is based on the treatment of the plant material 
with various solvents. It is based on the degree of solubility of flavonoids in organic solvents. The recovered aqueous extract was stored in the dark in hermetically sealed vials and subjected to chemical and biological analysis.

\section{Colorimetric determination of the flavonoïc extract}

The content of Euphorbia guyoniana in flavonoids was determined by the method of Aluminum Trichloride $\left(\mathrm{AlCl}_{3}\right)$ cited by Bahorun et al. (1996); Djeridane et al. (2006) and Ayoola et al. (2008). This method is based on the formation of an aluminum flavonoid-ion complex having a maximum absorbance at $430 \mathrm{~nm}$. The concentration of flavonoids was calculated from the calibration curve established with Quercetin and expressed in equivalent milligrams of Quercetin per gram of extract weight $(\mathrm{mg}$ $\mathrm{EQ} / \mathrm{gE})$.

\section{Infrared spectroscopy analysis of the extract}

The infrared spectrum of the aqueous extract, for a frequency range between 400 and $4000 \mathrm{~cm}^{-1}$, was obtained by a NICOLET 560 type spectrometer.

\section{High performance liquid chromatography (HPLC)}

Qualitative analysis of the aqueous extract was realized using HPLC. The apparatus consisted of a Young Line YL9100 liquid phase chromatograph, equipped with a YL 9101 quaternary pump with integrated degasifier YL 9101, a UV/Visible detector YL 9120 and a YL 9131 oven. The column used was Agilent eclips XDB C 18 (5 $\mu \mathrm{m})$ with a length of $25 \mathrm{~cm}$ and an internal diameter of $4.6 \mathrm{~mm}$. The mobile phase was a mixture of ultrapure water / acetonitrile / acetic acid (50:47:2.5) in an isocratic system with a flow rate of $1 \mathrm{ml} / \mathrm{min}$. The volume of extract and standards injected was $20 \mu \mathrm{l}$. The detection of the compounds was done with a UV detector at a wavelength of 280$320 \mathrm{~nm}$.

\section{Isolation and identification of pathogenic bacteria}

The bacteria were isolated from the soil of a henhouse in the Bouira region (Algeria). Soil sampling was carried out by the suspension-dilution method described by Vidhyasekaran et al. (1997). The identification of bacteria was made by fresh macroscopic observation based on morphological criteria of the colony, microscopic observation including methylene blue staining and Gram staining, biochemical galleries and confirmed by VITEK.

Several bacterial strains have been identified in this soil, such as E. coli which is a commensal bacterium of the human digestive tract as well as of many animals. At a rate of $10^{7}$ to $10^{9}$ Colony Forming Unit (CFU) per gram of faeces, it accounts for $80-90 \%$ of the most dominant species of the aerobic bacterial flora of the human intestine (Tenaillon et al., 2010). These strains are both responsible for intestinal and extraintestinal infections (urinary infections, bacteremias, meningitis ...) (Locatelli., 2013). It is mainly via the natural excretion of fecal matter by animals that these pathogenic bacteria have been introduced into aquifers, rivers and soil (Solo-Gabriele et al., 2000; An et al., 2002; Byappanahalli et al., 2006).

Enterococcus faecalis is also a commensal bacterium of the intestines of humans and warm-blooded animals. It is a species found in human excreta at concentrations ranging 
from $10^{5}$ to $10^{7}$ per gram of faeces (Noble, 1978; Leclerc et al., 1996). It is also found in faeces of animals such as cattle, poultry, pigs and sheep, but to a lesser extent (Leclerc et al., 1996; Franz et al., 1999; Wheeler et al., 2001). This species is an opportunistic pathogen, affecting only individuals with weakened immune systems, particularly in hospitals (Morrison et al., 1997). It may cause endocarditis, bacteremia, meningitis, urinary tract infections, intraabdominal infections and surgical wound infections (Chenoweth and Schaberg., 1990; Jett et al., 1994). Because of its natural presence in the intestines and fecal matter of humans and animals, this bacterium is frequently found in soil and on plants (Mundt., 1961; Fujioka et al., 1998; Byappanahalli et al., 2012; Valenzuela et al., 2012; Ran et al., 2013).

Staphylococcus aureus is a ubiquitous bacterium that is found specifically on mucous membranes, the nasopharyngeal sphere and skin of warm-blooded animals and humans (Ostyn et al., 2012). Staphylococci producing coagulases are essentially represented by the species Staphylococcus aureus. In addition to food poisoning and nosocomial infections in humans, this species may cause clinical and subclinical mastitis in ruminants, particularly cows, which is a common reason for milk contamination (Ostyn et al., 2012).

\section{Evaluation of the resistance of isolated bacteria to antibiotics}

The resistance of the isolated bacteria was tested by synthetic antibiotics, using the Muller Hinton agar diffusion method. The antibiotics used are Erythromycin $\left(\mathrm{E}_{15}\right)$ $(15 \mathrm{mcg})$ Ciproflaxacin $\left(\mathrm{Cip}_{5}\right)(5 \mathrm{mcg})$ Clindamycin $\left(\mathrm{Cl}_{25}\right)(25 \mathrm{mcg})$ Nalidixic Acid $\left(\mathrm{Na}_{30}\right)(30 \mathrm{mcg})$ and Carbenicillin $\left(\mathrm{Cb}_{100}\right)(100 \mathrm{mcg})$. Areas of inhibition were determined according to the recommendations of the National Committee for Clinical Laboratory Standards (NCCLS, 2006) and bacteria were classified as resistant or susceptible to antibiotics.

\section{Evaluation of the antibacterial activity}

The evaluation of the antibacterial activity of the aqueous extract of Euphorbia guyoniana was carried out by the diffusion method in agar medium recommended by several authors (Belaiche, 1979; Garbonnelle et al., 1987; Joffin and Leyral, 2014; Koba et al., 2004). Petri dishes containing the Muller Hinton agar were inoculated with a quantity of bacterial suspension ( $0.5 \mathrm{McFarland})$, according to the recommendations of the NCCLS. Sterilized paper discs of $6 \mathrm{~mm}$ of diameter, impregnated with $10 \mu \mathrm{L}$ of extract were placed on the surface of agar. The plates were kept for $2 \mathrm{~h}$ at $4{ }^{\circ} \mathrm{C}$ and then incubated overnight at $37^{\circ} \mathrm{C}$. The sensitivity of the strain to the extract is manifested by the size of the diameter of the bacterial-free zone surrounding the disc. The antimicrobial activity was determined by measuring the Minimum Inhibitory Concentrations (MICs). Three replicates are performed for each bacterium.

\section{Statistical analysis}

The results were expressed as mean \pm Standard Error of Mean $(M \pm E S M)$. The statistical analysis was performed using the Statistica software ${ }^{\circledR}$ (version 6, Genistat Conseils Inc., Montreal). After the analysis of the variance, the comparison of the averages is performed by the student's test for matched samples. The test is considered statistically significant when the value of $p$ is $\leq 0.05$, for a confidence interval of $95 \%$. 


\section{Results}

\section{Extraction yield on flavonoids}

Aqueous extract containing flavonoids was obtained with a yield of flavonoids of $1.7 \%$. The reason of using the aqueous extract for the study of the antibacterial activity in spite of its low rate is its richness in very polar flavonoids.

\section{Colorimetric determination of flavonoids}

The content in flavonoïds is reported in equivalent $\mathrm{mg}$ of quercetin/g of the plant. The concentration of the flavonoid in the aqueous extract is $0.31 \mathrm{mg} \mathrm{EQ} / \mathrm{gE}$.

\section{Infrared spectroscopy analysis of flavonoic extracts}

The results of the infrared characterization of the aqueous extract are shown in the Table 1 .

Table 1. Infrared analysis of the flavonoïc extract

\begin{tabular}{c|c|c|c}
\hline Wave lengh $\left(\mathbf{c m}^{-\mathbf{1}}\right)$ & Bonds & Nature of the bond & Function \\
\hline 3406.58 & $-\mathrm{OH}$ free & Broad band & Phenol \\
1609.47 & $\mathrm{C}=\mathrm{O}$ & Mean band & Aldehyde \\
1079.29 & $\mathrm{C}-\mathrm{O}$ & Weak band & Ester \\
\hline
\end{tabular}

In the aqueous extract of Euphorbia guyoniana, and referring to the work of Mabry et al. (1970), the broad band around $3406.58 \mathrm{~cm}^{-1}$ is associated with the elongation vibration of the $\mathrm{OH}$ bond (phenol function). The mean band at $1609.47 \mathrm{~cm}^{-1}$ corresponds to the elongation vibration of the $\mathrm{C}=\mathrm{O}$ bond (aldehyde function). Finally, a weak band of $1079.29 \mathrm{~cm}^{-1}$ is associated with the elongation vibration of the $\mathrm{C}-\mathrm{O}$ bond (ester function).

\section{HPLC}

The HPLC analysis revealed the presence of 41 compounds, of which 27 could be identified in the flavonoid extract of Euphorbia guyoniana (Fig. 1, Table 2).

Table 2. HPLC of the flavonoid extract of Euphorbia guyoniana

\begin{tabular}{c|c|c|c}
\hline Number & $\mathbf{R}_{\mathbf{T}}(\mathbf{M i n})$ & $\mathbf{\%}$ & Compound name \\
\hline $\mathbf{0 1}$ & 34.203 & 0.4 & P-coumaric acid \\
\hline $\mathbf{0 2}$ & 46.703 & 1.0 & Rosmarinic acid \\
\hline $\mathbf{0 3}$ & 62.753 & 2.0 & Quercetin \\
\hline $\mathbf{0 4}$ & 17.237 & 9.5 & Gallic acid \\
\hline $\mathbf{0 5}$ & 27.320 & 0.4 & caffeic acid \\
\hline $\mathbf{0 6}$ & 41.137 & 0.3 & Rutin \\
\hline $\mathbf{0 7}$ & 50.403 & 19.1 & Mllagic acid \\
\hline $\mathbf{0 8}$ & 56.103 & 6.6 & Syricetin \\
\hline $\mathbf{0 9}$ & 27.320 & 0.4 & Ferulic acid \\
\hline $\mathbf{1 0}$ & 37.903 & 0.2 &
\end{tabular}




\begin{tabular}{c|c|c|c}
\hline Number & $\mathbf{R}_{\mathbf{T}}$ (Min) & \% & Compound name \\
\hline $\mathbf{1 1}$ & 64.670 & 4.0 & Kaempferol \\
\hline $\mathbf{1 2}$ & 23.520 & 0.3 & Proanthocyanidin dimer \\
\hline $\mathbf{1 3}$ & 41.137 & 0.3 & Myricetin 3-O-glucoside \\
\hline $\mathbf{1 5}$ & 61.787 & 1.5 & Amentoflavone \\
\hline $\mathbf{1 6}$ & 45.320 & 1.6 & Isoferulic acid \\
\hline $\mathbf{1 7}$ & 47.953 & 2.5 & Quercetin-3- $\beta$-Ogalactoside \\
\hline $\mathbf{1 8}$ & 49.470 & 1.5 & Luteolin-7- $\beta$-Oglucoside \\
\hline $\mathbf{1 9}$ & 56.103 & 6.6 & Quercetin-3-O- $\alpha-$ rhamnoside \\
\hline $\mathbf{2 0}$ & 73.337 & 1.5 & Huteolin \\
\hline $\mathbf{2 1}$ & 10.187 & 4.4 & Apigenin-7-Oglucoside \\
\hline $\mathbf{2 2}$ & 58.370 & 3.0 & Apigenin-7-Orutinoside \\
\hline $\mathbf{2 3}$ & 54.737 & 4.7 & Luteolin-7-Oglucoside \\
\hline $\mathbf{2 4}$ & 49.470 & 1.5 & Salicyclic acid \\
\hline $\mathbf{2 5}$ & 23.520 & 0.3 & Benzoic Acid \\
\hline $\mathbf{2 6}$ & 43.053 & 0.3 & M-coumaric acid \\
\hline $\mathbf{2 7}$ & 47.953 & 2.5 & O-coumaric acid \\
\hline
\end{tabular}

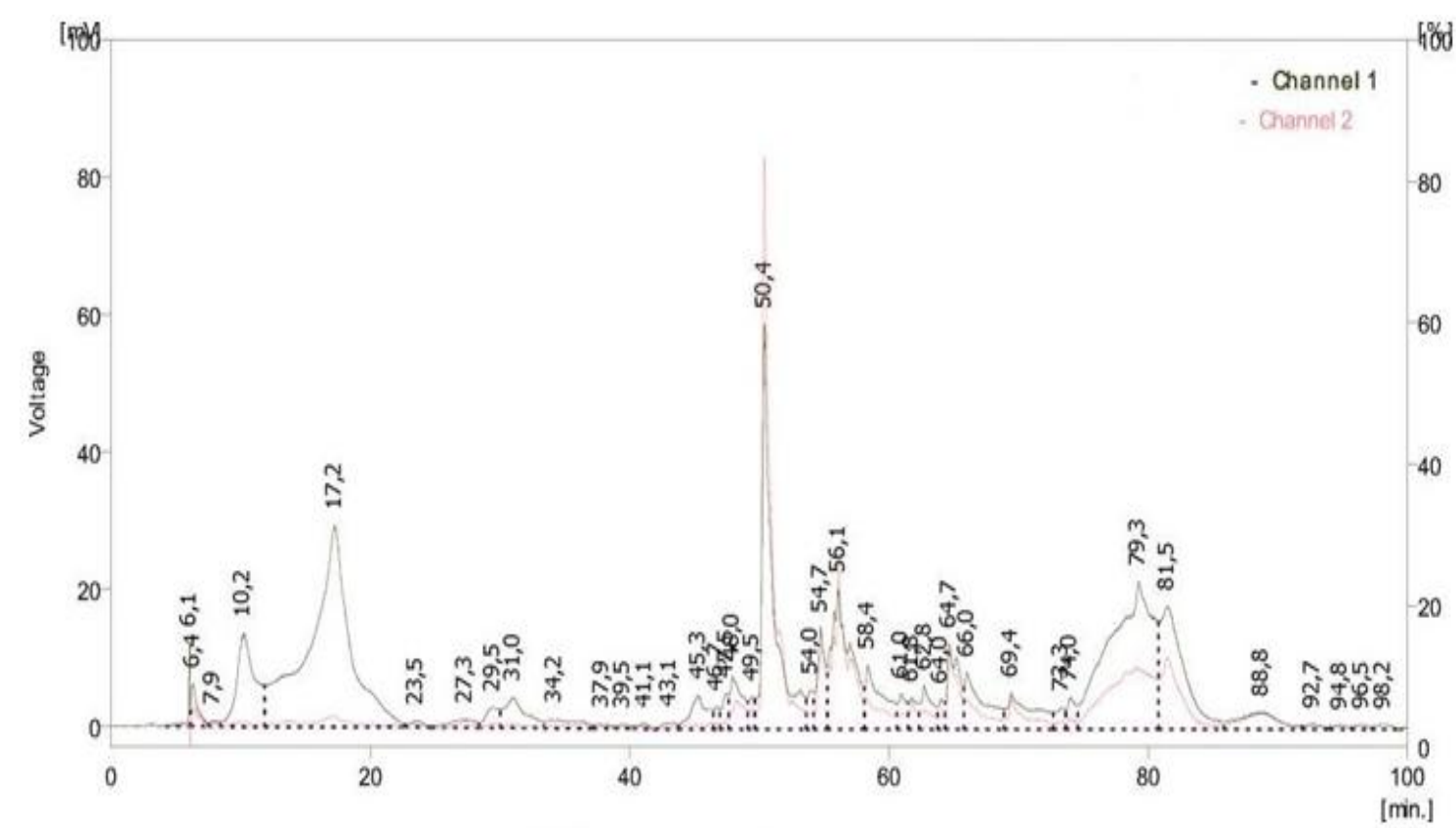

Figure 1. Chromatogram of HPLC applied to flavonoids

The analysis showed that the aqueous extract of Euphorbia guyoniana is rich in molecules with antibacterial activity. The major compounds are ellagic acid (19.1\%), gallic acid (9.5\%), Myricetine and Quercetin-3-O- $\alpha$-rhamnoside (6.6\%), Apigenin-7Orutinoside (4.7\%), Hydroxytyrosol (4.4\%) and Kaempferol (4.0\%), The other identified molecules are present at rates of less than $3 \%$. 


\section{Identification of isolated bacteria}

The results of the identification of isolated bacteria are shown in Tables 3 and 4 .

In total, twelve bacterial strains are isolated and identified from a henhouse soil belonging to three species: Escherichia coli (Gram negative), Staphylococcus aureus (Gram positive) and Enterococcus faecalis (Gram positive).

Table 3. Identification of bacterial strains

\begin{tabular}{|c|c|c|c|c|c|c|c|c|}
\hline \multirow[b]{2}{*}{ Sample } & \multicolumn{2}{|c|}{$\begin{array}{l}\text { Macroscopic } \\
\text { appearance }\end{array}$} & \multicolumn{2}{|c|}{$\begin{array}{l}\text { Microscopic } \\
\text { appearance }\end{array}$} & \multicolumn{2}{|c|}{ Culturing } & \multicolumn{2}{|c|}{ Biochemical tests } \\
\hline & Form & Size & $\begin{array}{l}\text { Fresh } \\
\text { state }\end{array}$ & $\begin{array}{c}\text { Gram } \\
\text { staining/ } \\
\text { Grouping } \\
\text { mode }\end{array}$ & $\begin{array}{l}\text { Culture } \\
\text { media }\end{array}$ & Conditions & Oxidase & Catalase \\
\hline 01 & $\begin{array}{c}\text { Very small } \\
\text { colony } \\
\text { Pink }\end{array}$ & $1 \mathrm{~mm}$ & $\begin{array}{c}\text { Cocci } \\
\text { immobile }\end{array}$ & $\begin{array}{c}\mathrm{G}+ \\
\text { Bunch of } \\
\text { grapes }\end{array}$ & CHAPMAN & $24 \mathrm{~h}$ at $37^{\circ} \mathrm{C}$ & - & + \\
\hline 02 & $\begin{array}{l}\text { Large colony } \\
\text { Yellowish }\end{array}$ & $3 \mathrm{~mm}$ & $\begin{array}{l}\text { Bacillus } \\
\text { mobile }\end{array}$ & $\begin{array}{c}\text { G- } \\
\text { Isolated }\end{array}$ & HEKTOEN & $24 \mathrm{~h}$ at $37^{\circ} \mathrm{C}$ & - & + \\
\hline 03 & $\begin{array}{c}\text { Large colony } \\
\text { Orange }\end{array}$ & $4 \mathrm{~mm}$ & $\begin{array}{c}\text { Bacillus } \\
\text { mobile }\end{array}$ & $\begin{array}{c}\text { G- } \\
\text { Diplocoque } \\
\end{array}$ & HEKTOEN & $24 \mathrm{~h}$ at $37^{\circ} \mathrm{C}$ & - & + \\
\hline 04 & $\begin{array}{c}\text { Small colony } \\
\text { Transparent }\end{array}$ & $1.5 \mathrm{~mm}$ & $\begin{array}{c}\text { Cocci } \\
\text { immobile }\end{array}$ & $\begin{array}{l}\text { G+ } \\
\text { Chain }\end{array}$ & BEA & $24 \mathrm{~h}$ at $37^{\circ} \mathrm{C}$ & - & - \\
\hline 05 & $\begin{array}{l}\text { Large colony } \\
\text { Salmon }\end{array}$ & $3 \mathrm{~mm}$ & $\begin{array}{l}\text { Bacillus } \\
\text { mobile }\end{array}$ & $\begin{array}{c}\text { G- } \\
\text { Diplocoque }\end{array}$ & HEKTOEN & $24 \mathrm{~h}$ at $37^{\circ} \mathrm{C}$ & - & + \\
\hline 06 & $\begin{array}{l}\text { Large colony } \\
\text { Yellowish }\end{array}$ & $4 \mathrm{~mm}$ & $\begin{array}{l}\text { Bacillus } \\
\text { immobile }\end{array}$ & $\begin{array}{c}\text { G- } \\
\text { Clusters }\end{array}$ & HEKTOEN & $24 \mathrm{~h}$ at $37^{\circ} \mathrm{C}$ & - & + \\
\hline 07 & $\begin{array}{l}\text { Small colony } \\
\text { Golden }\end{array}$ & $1.5 \mathrm{~mm}$ & $\begin{array}{c}\text { Cocci } \\
\text { immobile }\end{array}$ & $\begin{array}{c}\text { G+ } \\
\text { Bunch of } \\
\text { grapes }\end{array}$ & CHAPMAN & $24 \mathrm{~h}$ at $37^{\circ} \mathrm{C}$ & - & + \\
\hline 08 & $\begin{array}{l}\text { Very small } \\
\text { colony } \\
\text { Yellowish }\end{array}$ & $0.5 \mathrm{~mm}$ & $\begin{array}{c}\text { Cocci } \\
\text { immobile }\end{array}$ & $\begin{array}{c}\text { G+ } \\
\text { Bunch of } \\
\text { grapes } \\
\text { Isolated }\end{array}$ & CHAPMAN & $24 \mathrm{~h}$ at $37^{\circ} \mathrm{C}$ & - & + \\
\hline 09 & $\begin{array}{c}\text { Small colony } \\
\text { Whitish }\end{array}$ & $1.5 \mathrm{~mm}$ & $\begin{array}{c}\text { Cocci } \\
\text { immobile }\end{array}$ & $\begin{array}{c}\text { G+ } \\
\text { Chain } \\
\text { Diplocoque }\end{array}$ & BEA & $24 \mathrm{~h}$ at $37^{\circ} \mathrm{C}$ & - & - \\
\hline 10 & $\begin{array}{l}\text { small colony } \\
\text { Yellowish }\end{array}$ & $1.5 \mathrm{~mm}$ & $\begin{array}{c}\text { Cocci } \\
\text { immobile }\end{array}$ & $\begin{array}{c}\text { G+ } \\
\text { Bunch of } \\
\text { grapes }\end{array}$ & CHAPMAN & $24 \mathrm{~h}$ at $37^{\circ} \mathrm{C}$ & - & + \\
\hline 11 & $\begin{array}{c}\text { Small colony } \\
\text { Transparent } \\
\text { Surrounded } \\
\text { by a black } \\
\text { halo }\end{array}$ & $1.5 \mathrm{~mm}$ & $\begin{array}{c}\text { Cocci } \\
\text { immobile }\end{array}$ & $\begin{array}{c}\text { G+ } \\
\text { Chain } \\
\text { Isolated }\end{array}$ & BEA & $24 \mathrm{~h}$ at $37^{\circ} \mathrm{C}$ & - & - \\
\hline 12 & $\begin{array}{c}\text { Small colony } \\
\text { transparent }\end{array}$ & $0.5 \mathrm{~mm}$ & $\begin{array}{c}\text { Cocci } \\
\text { immobile }\end{array}$ & $\begin{array}{c}\text { G+ } \\
\text { Chain }\end{array}$ & BEA & $24 \mathrm{~h}$ at $37^{\circ} \mathrm{C}$ & - & - \\
\hline
\end{tabular}

+: presence; -: absence; G+: Gram positive; G-: Gram negative 
Table 4. Biochemical galleries

\begin{tabular}{|c|c|c|c|c|c|c|c|c|c|c|c|c|c|c|}
\hline \multirow{2}{*}{ Sample } & \multicolumn{13}{|c|}{ Biochemical galleries } & \multirow{2}{*}{ Name of the germ } \\
\hline & NR & Mob & Gaz & Glu & Suc & Lac & $\mathbf{H} 2 \mathrm{~S}$ & Urease & Indol & CIT & LDC & ODC & ADH & \\
\hline 01 & + & - & - & + & + & + & - & + & - & + & l & / & / & $\begin{array}{c}\text { Staphylococcus } \\
\text { aureus } \\
\text { (Staphylococcaceaes) }\end{array}$ \\
\hline $\mathbf{0 2}$ & + & + & + & + & + & + & - & - & + & - & + & + & - & $\begin{array}{c}\text { Escherichia coli } \\
\text { (Enterobacteriaceae) }\end{array}$ \\
\hline $\mathbf{0 3}$ & + & + & + & + & + & + & - & - & + & - & + & - & - & $\begin{array}{c}\text { Escherichia coli } \\
\text { (Enterobacteriaceae) }\end{array}$ \\
\hline 04 & + & - & - & + & + & + & - & - & - & - & - & + & + & $\begin{array}{l}\text { Enterococcus faecalis } \\
\text { (Streptococcaceae) }\end{array}$ \\
\hline 05 & + & + & + & + & + & + & - & - & + & - & + & + & - & $\begin{array}{c}\text { Escherichia coli } \\
\text { (Enterobacteriaceae) }\end{array}$ \\
\hline 06 & + & + & + & + & + & + & - & - & + & - & + & - & - & $\begin{array}{c}\text { Escherichia coli } \\
\text { (Enterobacteriaceae) }\end{array}$ \\
\hline 07 & + & - & - & + & + & + & - & + & - & + & I & I & I & $\begin{array}{c}\text { Staphylococcus } \\
\text { aureus } \\
\text { (Staphylococcaceaes) }\end{array}$ \\
\hline 08 & + & - & - & + & + & + & - & + & - & + & I & I & I & $\begin{array}{c}\text { Staphylococcus } \\
\text { aureus } \\
\text { (Staphylococcaceaes) }\end{array}$ \\
\hline 09 & + & - & - & + & + & + & - & - & - & - & - & + & + & $\begin{array}{l}\text { Enterococcus faecalis } \\
\text { (Streptococcaceae) }\end{array}$ \\
\hline 10 & + & - & - & + & + & + & - & + & - & + & I & I & I & $\begin{array}{c}\text { Staphylococcus } \\
\text { aureus } \\
\text { (Staphylococcaceaes) }\end{array}$ \\
\hline 11 & + & - & - & + & + & + & - & - & - & - & + & + & + & $\begin{array}{l}\text { Enterococcus faecalis } \\
\text { (Streptococcaceae) }\end{array}$ \\
\hline 12 & + & - & - & + & + & + & - & - & - & - & + & + & + & $\begin{array}{c}\text { Enterococcus faecalis } \\
\text { (Streptococcaceae) }\end{array}$ \\
\hline
\end{tabular}

+: presence; -: absence; /: unaccomplished

\section{Antibacterial activity}

Isolated strains used to evaluate antimicrobial activity showed an important resistance to the extract, Tables 5 and 6 show the results.

The results showed that the antibacterial activity of the aqueous extract of the plant differs from one strain to another. An important antibacterial activity of the extract is observed for Staphylococcus aureus with zones of inhibition ranging from $21( \pm 1)$ to $31.33( \pm 1.5) \mathrm{mm}$, and positive controls for Erythromycin, Ciproflaxacin And clindamycin which showed respectively clear inhibition zones of $6( \pm 0)$ to $34( \pm 1)$ $\mathrm{mm}, 6( \pm 0.5)$ to $36( \pm 0.5) \mathrm{mm}$ and $6( \pm 0)$ to $20( \pm 0.5) \mathrm{mm}$ according to the strain (Fig. 2). A high sensitivity of enterococcus faecalis to the extract was noted with zones of inhibition ranging from $22( \pm 2)$ to $28.33( \pm 1.2) \mathrm{mm}$, and also positive controls for Erythromycin, Ciproflaxacin, clindamycin, And nalidixic acid with inhibition zones of 6 $( \pm 0.5)$ to $20( \pm 2.6) \mathrm{mm}, 6( \pm 0)$ to $34( \pm 0) \mathrm{mm}, 618( \pm 0) \mathrm{mm}$ and $6( \pm 0.5)$ to $15( \pm$ 0) $\mathrm{mm}$ respectively (Fig. 3). Finally, a lower sensitivity was observed in Escherichia coli for the extract with an inhibition zone between $18.33( \pm 1.5)$ and $28.66( \pm 1.5) \mathrm{mm}$, 
and positive controls for Ciproflaxacin, Clindamycin and carbenicillin with inhibition zones of $40( \pm 0)$ to $42( \pm 1) \mathrm{mm}, 12( \pm 1)$ to $25( \pm 0) \mathrm{mm}$, and $8( \pm 0)$ to $32( \pm 1) \mathrm{mm}$ respectively (Fig. 4).

Table 5. Antibiotic and extract susceptibility tests

\begin{tabular}{|c|c|c|c|c|c|c|c|}
\hline \multirow{2}{*}{\multicolumn{2}{|c|}{ Strain }} & \multicolumn{5}{|c|}{ Areas of Antibiotic Inhibition } & \multirow{2}{*}{$\begin{array}{l}\text { Areas of extract } \\
\text { inhibition }\end{array}$} \\
\hline & & $\mathbf{E}_{15}$ & $\mathbf{C l}_{25}$ & $\mathrm{Cip}_{5}$ & $\mathrm{Cb}_{100}$ & $\mathbf{N A}_{\mathbf{3 0}}$ & \\
\hline \multirow{4}{*}{ Escherichia coli } & 01 & 1 & $16(\mathrm{~S})$ & $41(\mathrm{~S})$ & $13(\mathrm{~S})$ & I & $28(\mathrm{~S})$ \\
\hline & 02 & l & $12(\mathrm{~S})$ & $42(\mathrm{~S})$ & $32(\mathrm{~S})$ & I & $19(\mathrm{~S})$ \\
\hline & 03 & I & $16(S)$ & $42(\mathrm{~S})$ & $24(S)$ & I & $20(S)$ \\
\hline & 04 & I & $25(S)$ & $40(\mathrm{~S})$ & $8(S)$ & I & $18(\mathrm{~S})$ \\
\hline \multirow{4}{*}{$\begin{array}{c}\text { Staphylococcus } \\
\text { aureus }\end{array}$} & 01 & $6(\mathrm{R})$ & $6(\mathrm{R})$ & $6(\mathrm{R})$ & 1 & I & $21(S)$ \\
\hline & 02 & $34(\mathrm{~S})$ & $8(S)$ & $34(\mathrm{~S})$ & 1 & I & $28(S)$ \\
\hline & 03 & $24(S)$ & $18(S)$ & $36(\mathrm{~S})$ & 1 & I & $27(S)$ \\
\hline & 04 & $34(\mathrm{~S})$ & $20(S)$ & $36(S)$ & I & I & $32(\mathrm{~S})$ \\
\hline \multirow{4}{*}{$\begin{array}{l}\text { Enterococcus } \\
\text { faecalis }\end{array}$} & 01 & $6(\mathrm{R})$ & $6(\mathrm{R})$ & $6(\mathrm{R})$ & 1 & $6(\mathrm{R})$ & $28(S)$ \\
\hline & 02 & $18(\mathrm{~S})$ & $12(\mathrm{~S})$ & $16(\mathrm{~S})$ & 1 & $15(\mathrm{~S})$ & $22(S)$ \\
\hline & 03 & $20(S)$ & $18(\mathrm{~S})$ & $34(\mathrm{~S})$ & 1 & $6(\mathrm{R})$ & $28(\mathrm{~S})$ \\
\hline & 04 & $6(\mathrm{R})$ & $6(\mathrm{R})$ & $6(\mathrm{R})$ & I & $6(\mathrm{R})$ & $26(S)$ \\
\hline
\end{tabular}

S: sensitive; R: resistant; /: unaccomplished

Table 6. Values of minimum inhibitory concentrations

\begin{tabular}{|c|c|c|}
\hline \multicolumn{2}{|c|}{ Strain } & $\underset{(\mathrm{mg} / \mathrm{ml})}{\mathrm{MIC}_{\mathrm{S}}}$ \\
\hline \multirow{4}{*}{ Escherichia coli } & 01 & 61.78 \\
\hline & 02 & 55.12 \\
\hline & 03 & 55.12 \\
\hline & 04 & 50.23 \\
\hline \multirow{4}{*}{ Staphylococcus aureus } & 01 & 1.47 \\
\hline & 02 & 8.88 \\
\hline & 03 & 3.25 \\
\hline & 04 & 4.75 \\
\hline \multirow{4}{*}{ Enterococcus faecalis } & 01 & 23.23 \\
\hline & 02 & 25.87 \\
\hline & 03 & 19.87 \\
\hline & 04 & 17.05 \\
\hline
\end{tabular}

From the results obtained above, it is clear that the aqueous extract of Euphorbia guyoniana is much more active against the different microbial strains than the synthetic antibiotics by exhibiting larger zones of inhibition. These results are confirmed by significant tests with $\mathrm{p}<0.05$. Except for Ciproflaxacin, which exhibits slightly larger inhibition zones on the Escherichia coli strains compared to the extract. This important antibacterial activity is due to the richness of the extract in flavonoïds, known to be effective antibacterial substances. 


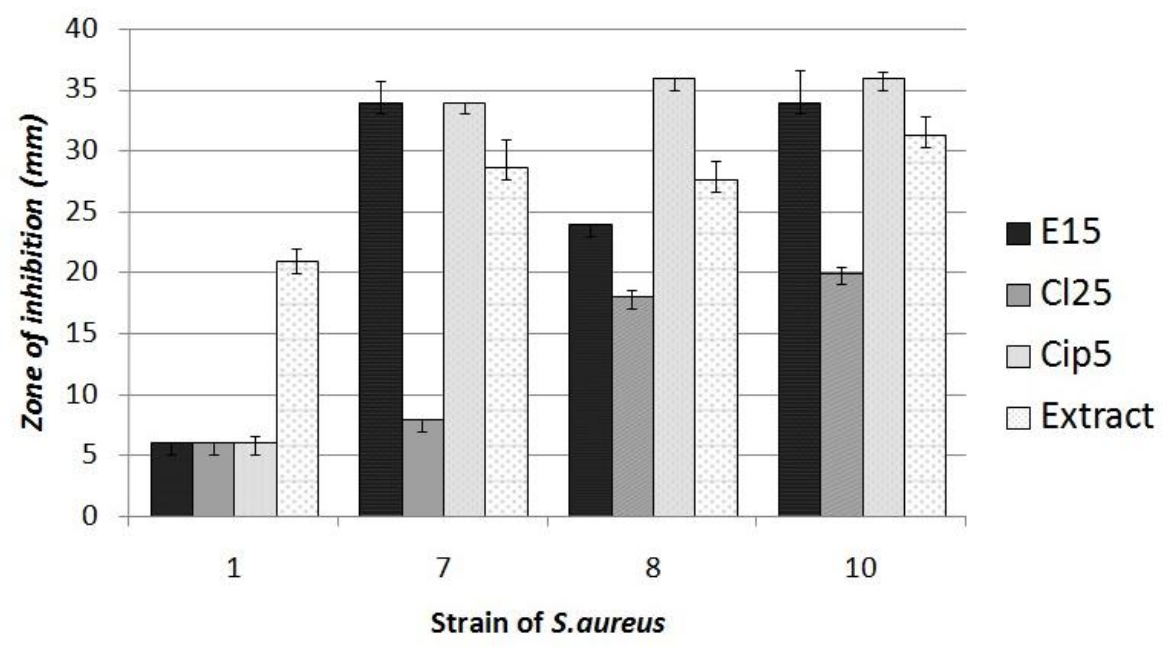

Figure 2. Sensitivity of $S$. aureus strains of the extract and antibiotics

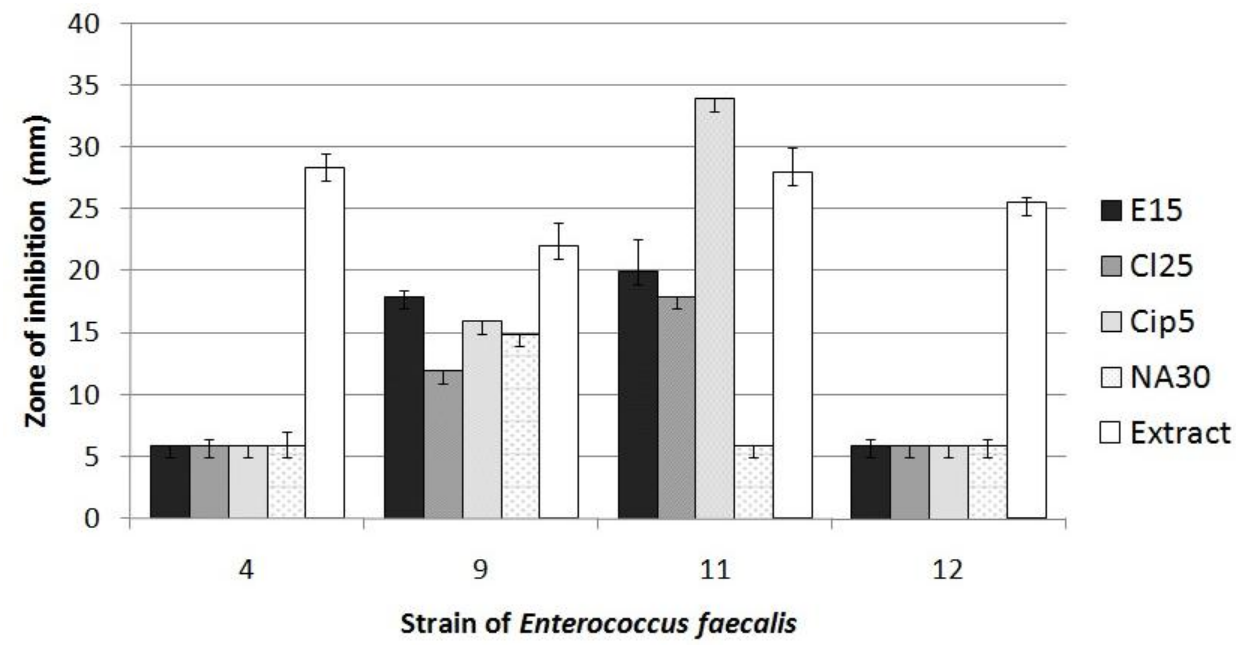

Figure 3. Sensitivity of the strains Enterococcus faecalis to the extract and antibiotics

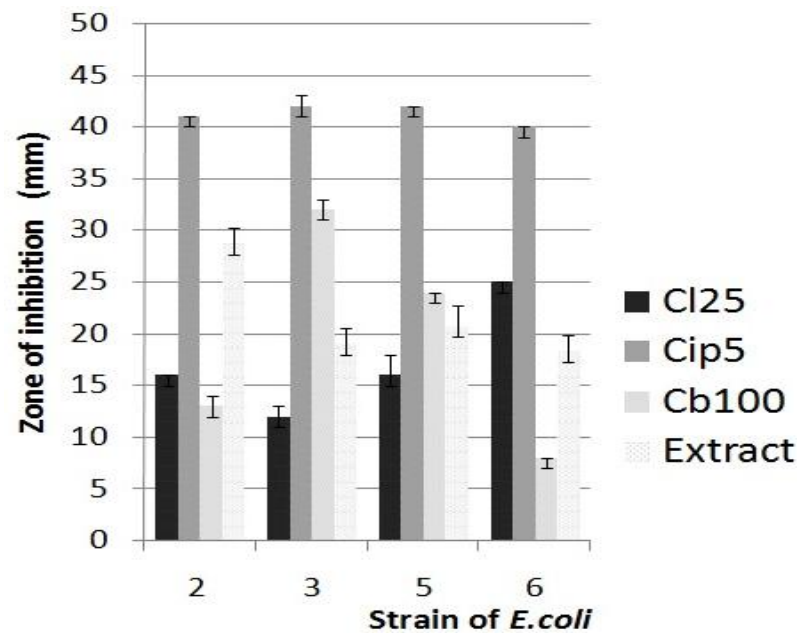

Figure 4. Sensitivity of E. coli to the extract and antibiotics 


\section{Discussion}

The value of the flavonoid yield of the Euphorbia guyoniana plant found in our study $(1.7 \%)$ was higher than that obtained by Kemassi (2014) for the aqueous extract of the same plant harvested from the Ghardaiia region which was obtained by Maceration with acetone, ie $0.082 \%$. In addition, higher yields were noted by Herouini et al. (2015) for the flavonoid extract of the roots $(6.3 \%)$ and the aerial part $(4.3 \%)$ of Euphorbia guyoniana harvested in Oued sebseb (Algerian Sahara) obtained by reflux. According to Haba et al. (2008), Euphorbia guyoniana is a plant rich in secondary metabolites including diterpenes, triterpenes, steroids and aromatic compounds. The yield of flavonoids appears to depend on the nature of the biotope and the extraction method, knowing that the number of washes carried out in the extraction protocol could lead to substantial losses of the aglycones, hence the disadvantages of the method of extraction by solvent confrontation. Similar works have reported the existing of variability in the yield values extraction of secondary metabolite depending on the procedure of extraction (Moreira et al., 2005; Sagdic and Ozcan, 2003; Celiktas et al., 2007; Turkmen et al., 2007).

Concerning the concentration of aqueous extract in flavonoids; Andrianarisoa and Tsirinirindravo (2009) found a concentration of approximately $63.39 \mu \mathrm{g} / \mu \mathrm{l}$ for the aqueous extract of the leaves of Dalechampia clematidifolia (Euphorbiaceae) harvested in Madagascar, which represents a significantly lower value to that found for the species Euphorbia guyoniana.

HPLC analysis by Smara et al. (2014) on the aerial parts of the same plant (Euphorbia guyoniana) harvested from the Oued Souf region (Algerian Sahara) revealed the presence of a hydrolyzable tannin, a single coumarin and two flavonoids (flavonol) namely Quercetin-3O- $\beta$-D-glucuronide and kaempferol-3O- $\beta$-D-glucuronide. In our study, Quercetin is detected as a molecule, and associated with galactoside, glucoside or rhamnoside. As for kaempferol, this compound is also identified in the free form.

Very little study concerning the antibacterial activity of the aqueous extract of Euphorbia guyoniana was carried out. Herouni et al. (2015) used separately the flavonoid aqueous extracts of the aerial and subterranean parts of Euphorbia guyoniana on Staphylococcus aureus and Escherichia coli isolated from several infections, and noted a less marked activity than that observed in our study. These authors obtained zones of inhibition comprised between 7 and $8 \mathrm{~mm}$.

This difference in the inhibitory effect of the bacterial growth observed may be related to the richness of the extract tested in flavonoid compounds known for their antibacterial activity. In the case of this study, the important antibacterial effect observed can be attributed either to the richness of the extract of flavonoid compounds (ellagic acid, gallic acid, Myricetine, Quercetin-3-O- $\alpha$-rhamnoside, ApigeninOrutinoside, Hydroxytyrosol and Kaempferol) or to the virulence of the bacterial strain.

Moreover, the efficiency of an extract of a plant also depends on the extraction method (Moreira et al., 2005; Sagdic and Ozcan, 2003; Celiktas et al., 2007; Turkmen et al., 2007), the part of the plant used (Yeo Sounta, 2014; Natarajan et al., 2005) and the harvest season. 


\section{Conclusion}

The evaluation of the antibacterial activity of the aqueous flavonoid extract of the medicinal plant Euphorbia guyoniana showed a remarkable inhibitory effect on pathogenic bacteria of telluric origin. In perspective other studies are necessary for the development of formulations for pharmaceutical use based on this extract in order to fight against these pathogens.

Acknowledgements. The authors gratefully acknowledge the precious help of the Center for Scientific and Technical Research in Physico-Chemical Analysis (CRAPC) of Algeria and the Department of Biology of the University of Boumerdes of Algeria for valuable technical assistance.

This research did not receive any specific grant from funding agencies in the public, commercial, or notfor-profit sectors.

\section{REFERENCES}

[1] An, Y. J., Kampbell, D. H., Breidenbach, G. P. (2002): Escherichia coli and total coliforms in water and sediments at lake marinas. - Environ. Pollut. 120(3): 771-778.

[2] Andrianarisoa, B., Tsirinirindravo, L. H. (2009): Antibacterial activities of leaf extract of Dalechampia clematidifolia (Euphorbiaceae). - Int. J. Biol. Chem. Sci. 3(5): 1198-1202.

[3] Ayoola, G., Coker, H., Adesegun, S., Adepoju-Bello, A., Obaweya, K., Ezennia, E., Atangbayila, T. (2008): Phytochemical Screening and Antioxidant Activities of Some Selected Medicinal Plants Used for Malaria Therapy in Southwestern Nigeria. - Trop. J. Pharm. Res. 7(3): 1019-1024.

[4] Bahorun, T., Grinier, B., Trotin, F., Brunet, G., Din, T., Luncky, M., Vasseur, J., Cazin, M., Cazin, C., Pinkas, M. (1996): Oxygen species scavenging activity of phenolic extracts from hawthorn fresh plant organs and pharmaceutical preparations. Arzneimittelforschung 46(11): 1086-1089.

[5] Belaiche, P. (1979): Traité de phytothérapie et d'aromathérapie Tome 1. L'aromatogramme. - M. S. A., Paris.

[6] Bellakhdar, J. (1997): La Pharmacopée Marocaine Traditionnelle. Médecine arabe ancienne et savoirs populaires. - Ibis Press, Paris.

[7] Berg, G., Eberl, L., Hartmann, A. (2005): The rhizosphere as a reservoir for opportunistic human pathogenic bacteria. - Environ. Microbiol. 7(11): 1673-1685.

[8] Bruneton, J. (1999): Pharmacognosie, Phytochimie, Plantes médicinales. Tec \& Doc. Editions médicales internationals, Paris.

[9] Byappanahalli, M. N., Whitman, R. L., Shively, D. A., Sadowsky, M., Ishii, S. (2006): Population structure, persistence, and seasonality of autochthonous Escherichia coli in temperate, coastal forest soil from a Great Lakes watershed. - Environ. Microbiol. 8(3): 504-513.

[10] Byappanahalli, M., Roll, B., Fujioka, R. (2012): Evidence for occurrence, persistence, and growth potential of Escherichia coli and Enterococci in Hawaii's soil environments. - Microb. Environ. 27(2): 164-170.

[11] Celiktas, O. Y., Hames Kocabas, E. E, Bedir, E., Vardar Sukan, F., Ozek, T., Base, K. H. C. (2007): Antimicrobial activities of methanol extracts and essential oils of Rosmarinus officinalis, depending on location and seasonal variations. - Food Chem. 100(2): 553559.

[12] Chenoweth, C., Schaberg, D. (1990): The epidemiology of enterococci. - Eur. J. Clin. Microbiol. 9(2): 80-89.

[13] Colinon, C., Deredjian, A., Hien, E., Brothier, E., Bouziri, L., Cournoyer, B., Hartman, A., Henry, S., Jolivet, C., Ranjard, L. (2013): Detection and enumeration of Pseudomonas 
aeruginosa in soil and manure assessed by an ecfX qPCR assay. - J Appl Microbiol 114(6): 1734-1749.

[14] De Nazaré, D., Sebastião, F., Palmeira, J., Conserva, L., Lyra Lemos, R. (2005): Quinoline alkaloïds from Sebastiania corniculata (Euphorbiaceae). - Biochem. Syst. Ecol. 33(5): 555-558.

[15] Djeridane, A., Yousfi, M., Nadjemi, B., Boutassouna, D., Stocker, P., Vidal, N. (2006): Antioxidant activity of some Algerian medicinal plants extracts containing phenolic compounds. - Food Chem. 97(4): 654-660.

[16] Franz, C. M. A. P., Holzapfel, W. H., Stiles, M. E. (1990): Enterococci at the crossroads of food safety?. - Int J Food Microbiol 47(1-2): 1-24.

[17] Freitag, N. E., Port, C. G., Miner, M. D. (2009): Listeria monocytogenes from saprophyte to intracellular pathogen. - Nat. Rev. Microbiol. 7(9): 623-628.

[18] Fujioka, R., Sian-Denton, C., Borja, M., Castro, J., Morphew, K. (1998): Soil: the environmental source of Escherichia coli and Enterococci in Guam's streams. - J Appl Microbiol 85(1): 83S-89S.

[19] Garbonnelle, B., Dens, F., Marmonier, A., Pinon, G., Vargues, R. (1987): Bactériologie médicale Techniques usuelles. - SIMEP, Paris.

[20] Haba, H. (2008): Etude phytochimique de deux Euphorbiaceae sahariennes: Euphorbia guyoniana Boiss. \& Reut. et Euphorbia retusa Forsk. - PhD Thesis, University of Batna, Algeria.

[21] Herouini, A., Kemassi, A., Ould El Hadj, M. D. (2015): Etude de l'activité biologique des extraits aqueux d'Euphorbia guyoniana (Euphorbiaceae) récoltée dans Oued Sebseb (Sahara Algérien). - el-wahat 8(2): 15-25.

[22] Hunsa, P., Chulabhorn, M., Ruchirawat, S., Prawat, U., Tuntiwachwuttikul, P., Tooptakong, U., Taylor, W. C., Pakawatchai, C., Brian, W., Skelton, B. W., Allen, H. (1995): Cyanogenic and non-cyanogenic glycosides from Manihot esculenta. Phytochemistry 40(4): 1167-1173.

[23] Jett, B. D., Huycke, M. M., Gilmore, M. S. (1994): Virulence of enterococci. - Clin. Microbiol. Rev 7(4): 462-478.

[24] Joffin, N., Leyral, G. (2014): Microbiologie technique. Dictionnaire des techniques. Canopé-CRDP, Bordeaux.

[25] Kemassi, A. (2014): Toxicité comparée des extraits d'Euphorbia guyoniana (Stapf.) (Euphorbiaceae), Cleome arabica L. (Capparidaceae) et de Capparis spinosa L. (Capparidaceae) récoltés de la région de Ghardaïa (Sahara septentrional) sur les larves du cinquième stade et les adultes de Schistocerca gregaria (Forskal, 1775) (OrthopteraCyrtacanthacridinae). - PhD Thesis, Kasdi Merbah University, Ouargla, Algeria.

[26] Koba, K., Sanda, K., Raynaud, C., Nenonene, Y. A., Millet, J., Chaumont Loziene, K., Venskutonis, P. R., Sipailien, A., Labokas, J. (2017): Radical scavenging and antibacterial properties of the extracts from different Thymus pulegioides L. chemotypes. - Food Chem 103(2): 546-559.

[27] Leclerc, H., Devriese, L. A, Mossel, D. A. A. (1996): Taxonomical changes in intestinal (faecal) enterococci and streptococci: consequences on their use as indicators of faecal contamination in drinking water. - J Appl Microbiol 81(5): 459-466.

[28] Locatelli, A. (2013): Prévalence de pathogènes humains dans les sols français, effet des facteurs pédoclimatiques, biologiques et du mode d'utilisation des sols. - $\mathrm{PhD}$ Thesis, Université de Bourgogne, Dijon, France.

[29] Mabry, T. J., Markham, K. R., Thomas, M. B. (1970): The Systematic Identification of Flavonoids. - Springer, New York.

[30] Mavar, M. H., Brick, D., Marie, D. E. P., Quetin-Leclercq, J. (2004): In vivo antiinflammatory activity of Alchornea cordifolia (Schumach. \& Thonn.) Müll. Arg. (Euphorbiaceae). - J Ethnopharmacol 92(3): 209-214. 
[31] Mazoir, N. A., Benharref, M., Bailén, M., Reina, M., Onzálezcoloma, A. (2008): Bioactive triterpene derivatives from latex of two Euphorbia species. - Phytochemistry 69(6): 1328-1338

[32] Moreira, M. R., Ponce, A. G., Del Valle, C. E., Roura, S. I. (2005): Inhibitory parameters of essential oils to reduce a foodborne pathogen. - Food Sci. Technol. 38(5): 565-570.

[33] Morrison, D., Woodford, N., Cookson, B. (1997): Enterococci as emerging pathogens of humans. - J Appl Microbiol 83(S1): 89S-99S.

[34] Mundt, J. O. (1961): Occurrence of Enterococci: bud, blossom, and soil studies. - Appl Microbiol 9(6): 541-544.

[35] Natarajan, K., Kumaresan, V., Narayanan, K. (2005): A check list of Indian agarics and boletes (1984-2002). - Kavaka 33: 61-128.

[36] Noble, C. J. (1978): Carriage of group D streptococci in the human bowel. - J Clin Pathol 31(12): 1182-1186.

[37] Ostyn, A., De Buyser, M. L., Guillier, F., Krys, S., Hennekinne, J. A. (2012): Benefits of the combined use of immunological- and PCR- based methods for determination of staphylococcal enterotoxin food safety criteria in cheese. - Food Anal Methods 2: 173178.

[38] Raaijmakers, J. M., Timothy, C. P., Steinberg, C., Alabouvette, C., Moënne-Loccoz, Y. (2009): The rhizosphere: a playground and battlefield for soilborne pathogens and beneficial microorganisms. - Plant Soil 321(1): 341-361.

[39] Ran, Q., Badgley, B. D., Dillon, N., Dunny, G. M., Sadowsky, M. J. (2013): Occurrence, genetic diversity, and persistence of Enterococci in a lake superior watershed. - Appl. Environ. Microbiol. 79(9): 3067-3075.

[40] Reis, A. L. S., Montanhini, M. T. M., Bittencourt, J. V. M., Destro, M. T., Bersot, L. S. (2014): Gene detection and toxin production evaluation of hemolysin BL of Bacillus cereus isolated from milk and dairy products marketed in Brazil. - Braz J Microbiol 44(4): 1195-1198.

[41] Sagdic, O., Ozcan, M. (2003): Antibacterial activity of Turkish spice hydrosols. - Food Control 14(3): 141-143.

[42] Smara, O., Julia, A., Moral-Salmi, C., Vigor, C., Vercauteren, J., Legseir, B. (2014): Flavonoïds from Euphorbia guyoniana Boissier \& Reuter. - J. Life Sci 8(6): 544-551.

[43] Smith, L. D. (1978): The occurrence of Clostridium botulinum and Clostridium tetani in the soil of the United States. - Health Lab Sci 15(2): 74-80.

[44] Smith, L. D. S. (1979): Clostridium botulinum: Characteristics and occurrence. - Rev Infect Dis 1(4): 637-641.

[45] Solo-Gabriele, H. M., Wolfert, M. A., Desmarais, T. R., Palmer, C. J. (2000): Sources of Escherichia coli in a coastal subtropical environment. - Appl Environ Microbiol 66(1): 230-237.

[46] Tenaillon, O., Skurnik, D., Picard, B., Denamur, E. (2010): The population genetics of commensal Escherichia coli. - Nature Rev. Microbiol. 8(3): 207-217.

[47] Ticknor, L. O., Kolsto, A. B., Hill, K. K., Keim, P., Laker, M. T., Tonks, M., Jackson, J. P. (2001): Fluorescent amplified fragment length polymorphism analysis of Norwegian Bacillus cereus and Bacillus thuringiensis soil isolates. - Appl Environ Microbiol 67(10): 4863-4873.

[48] Tramier, R. (1986): Pathogens from land-based sources; Means of intervention and biocenosis. - OEPP Bull 16(2): 299-310.

[49] Tripathi, R. D., Tiwari, K. P. (1980): Geniculatin, a triterpenoid saponin from Euphorbia geniculata. - Phytochem 19(10): 2163-2166.

[50] Turkmen, N., Velioglu, Y. S, Sari, F., Polat, G. (2007): Effect of extraction conditions on measured total polyphenol contents and antioxidant and antibacterial activities of black tea. - Molecules 12(3): 484-496. 
[51] Valenzuela, A. S., Benomar, N., Abriouel, H., Pulido, R. P., Cañamero, M. M., Gálvez, A. (2012): Characterization of Enterococcus faecalis and Enterococcus faecium from wild flowers. - Anton. Leeuw. Int. J. G 101(4): 701-711.

[52] Vidhyasekaran, P., Sethuraman, K., Rajappan, K., Vasumathi, K. (1997): Powder formulations of Pseudomonas fluorescens to control pigeonpea wilt. - Bio. Control 8(3) 166-171.

[53] Wheeler, A. L., Hartel, P. G., Godfrey, D. G., Hill, J. L., Segars, W. I. (2001): Potential of as a human fecal indicator for microbial source tracking. - J. Environ. Qual. 31(4): 1286-1293.

[54] Yeo Sounta, O., Guessennd Kouadio, N., Meité, S., Ouattara, K., Bahi Gnogbo, A., N'Guessan, J. D., Coulibaly, A. (2014): In vitro antioxidant activity of extracts of the root Cochlospermum planchonii Hook. f. ex. Planch (Cochlospermaceae). - J. Pharmacogn. Phytochem. 3(4): 164-170. 